\title{
Environmental alignment between logistics service providers and shippers - a supply chain perspective
}

Maria Huge-Brodin, Edward Sweeney and Pietro Evangelista

The self-archived postprint version of this journal article is available at Linköping University Institutional Repository (DiVA):

http://urn.kb.se/resolve?urn=urn:nbn:se:liu:diva-169325

N.B.: When citing this work, cite the original publication.

Huge-Brodin, M., Sweeney, E., Evangelista, P., (2020), Environmental alignment between logistics service providers and shippers - a supply chain perspective, International Journal of Logistics Management. https://doi.org/10.1108/IJLM-04-2019-0101

Original publication available at:

https://doi.org/10.1108/IJLM-04-2019-0101

Copyright: Emerald

http://www.emeraldinsight.com/ 


\title{
Environmental Alignment between \\ Logistics Service Providers and Shippers - \\ a Supply Chain Perspective
}

\begin{abstract}
Purpose

Various suggested paths for greening logistics and supply chains often address the specific perspectives of single supply chain actors. Drawing on stakeholder theory, the purpose of this paper is to develop a deeper understanding of the alignment between logistics service providers (LSPs) and shippers in the context of adopting more environmentally sustainable logistics practices.

\section{Design/methodology/approach}

With a case study approach, a dual perspective is taken in which both LSPs and shippers were researched. The cases comprise eight LSPs and six shipper companies in Sweden, Italy and Ireland. Information was first analysed in relation to: levels of environmental awareness; customer requirements and provider offerings; and, critical success factors (CSFs) and inhibitors. In a second step, the findings were analysed using stakeholder theory.
\end{abstract}

\section{Findings}

LSPs demonstrate higher ambition levels and more concrete offerings compared to shippers' requirements for green logistics services. Paradoxically, customers are an important CSF, and also an inhibitor for both LSPs and shippers. Both LSPs and shippers perceive financial factors and senior management priorities as important CSFs. The application of stakeholder theory helps to illuminate the importance of the many secondary stakeholders $v s$ that of one or a relatively small number of primary stakeholders.

\section{Originality/value}

The three-dimensional analysis of environmental alignment between LSPs and shippers reinforces existing knowledge and provides new insights. A novel use of stakeholder theory in a supply chain context underlines its usefulness in research of this kind.

Keywords: LSPs, Shippers, Buyers, Environmental alignment, Green logistics, Stakeholder theory, Case study analysis.

Article classification: Research paper 


\section{Introduction}

The anthropogenic impact of logistics activities is now widely understood (see for example: McKinnon, 2018). In this context, the development of more environmentally sustainable logistics practices has a key role to play in meeting the demanding targets to which governments around the world are now committed. It is not surprising, therefore, that recent years have seen a strong focus amongst policy makers, supply chain practitioners and researchers on the factors that influence the adoption of greener logistics practices. Nevertheless, many factors and initiatives are studied in quite narrow contexts - this article adopts a more integrated approach.

Research in green logistics has identified several ways for companies to reduce the environmental impact of transport and logistics activities. These include modal shift and intermodal solutions (McKinnon, 2018; Woodburn and Whiteing, 2010), effective adoption of advanced technology solutions (Johannes et al., 2018; Wang et al. 2015; McKinnon, 2010), use of tools for assessing the carbon footprint of activities (Kang et al., 2013; Eglese and Black, 2010; Lieb and Lieb, 2010; Piecyk, 2010), environmentallyoriented transport management (Bajec et al. 2015; Lieb and Lieb, 2010), and green logistics system design (Colicchia et al., 2013; Harris et al., 2010; Kohn and Huge-Brodin, 2008; Aronsson and Huge-Brodin, 2006). However, it appears that the actual adoption of these practices is taking place at a relatively slow pace (see, for example: Evangelista et al., 2017; Perotti et al., 2012)

Logistics systems include a variety of actors, each of which has its own strategic goals and priorities. Two of the core actors are logistics service providers (LSPs) and shippers (typically retailers and manufacturers, i.e. the customers of LSPs). In the context of green logistics, LSPs are crucial players as they manage the systems and actually perform the operations that ultimately produce emissions (Evangelista, 2014; Tacken et al., 2014; Aronsson and Huge-Brodin, 2006; McKinnon, 2003).

One important impediment to the greening of logistics activities that has been suggested is the tension between LSPs and shippers (see, for example: Wolf and Seuring, 2010). This tension manifests itself in various ways including lack of trust and poor levels of environmental knowledge sharing (ibid). Previous research in this area is somewhat fragmented in the sense that, with few exceptions, it deals with either the LSP or the shipper side in isolation. Furthermore, much of the relevant extant scholarship deals with relatively narrow, single subject topics that represents just part of the overall picture. This is a serious gap in our understanding of the subject, one which this paper seeks to address squarely, by addressing a combination of related questions.

Among the relatively few studies that consider both sides, a number of key themes arise. Studies point to a mismatch between shippers' offerings and LSPs requirements (Martinsen and Björklund, 2012; Martinsen and Huge-Brodin, 2014), where shippers' environmental demands tend to be weaker and less specific than the offerings from LSPs (Kudla and Klaas-Wissing, 2012; Martinsen and Björklund, 2012). Shippers' lack of green awareness could be one explanation for the imbalance (Martinsen, 2014; Vieira et al.; 2016). It has also been suggested that cross-functional and cross-organizational activities through various coordination mechanisms may improve alignment between shippers and LSPs with respect to environmental endeavours (Jørsfeldt et al., 2016: Sallnäs, 2016). In response to the various findings that have been presented in relation to shipper-LSP 
alignment, there is a need for an integrated approach which offers explanations aiming to improve understanding of shipper-LSP alignment.

In order to understand how LSPs and shippers manage their green logistics initiatives, with the aim of collaborating more effectively and efficiently, it is important to consider their different perspectives and roles. As a consequence a dual perspective on green logistics initiatives among LSPs and shippers is applied. The basic assumption is that the more LSPs and shippers are aligned, the greener the supply chain is likely to be. The overall purpose of the research described in this article is to develop a better understanding of the nature of this alignment between LSPs and shippers in the context of adopting more environmentally sustainable logistics practices.

Apart from each other, both LSPs and shippers are affected by many supply chain actors, with other stakeholders potentially playing important but different roles for LSPs and shippers. Our primary focus is on the greening of logistics practices with a particular emphasis on how LSP/shipper alignment can support this process. In previous research relating to green supply chain management (GSCM), stakeholder theory has been suggested (Sarkis et al., 2011) and used (Ferguson, 2011) to capture and analyse the wider context where multiple actors are involved. Stakeholder theory is based on the recognition that many actors affect a firm's decision making processes. By adopting stakeholder theory as a prism through which to consider empirical evidence - in this case from in-depth case studies undertaken in three countries - we aim to develop a deeper and richer understanding of the various roles that different stakeholders have in the development and adoption of green logistics practices. Stakeholder theory will thus be used as a conceptual framework to improve understanding of the alignment between LSPs and shippers.

In this article, alignment refers to the extent to which actors adjust to "the other side", i.e. LSPs to shippers, and shippers to LSPs, respectively, with the goal of smoothing the interaction and thereby supporting a more efficient and effective supply chain. The authors take inspiration from Gattorna (1998), who stresses behavioural aspects in improving supply chain performance. Gattorna (ibid.) developed a widely cited strategic alignment model, which “...brings together the external market's dynamics, the firm's strategic response(s) and the firm's internal capability." (p 2). In this article, this thinking is applied to the behaviour of interacting organisations in three interconnected dimensions: levels of awareness; practices in terms of customer requirements and provider offerings; and, critical success factors and inhibitors to success. Our three research questions (RQs), the derivation of which is described in detail in sections 2.1, 2.2 and 2.3, relate explicitly to these three dimensions:

RQ1: In relation to the environmental dimension, how do levels of awareness align between LSPs and shippers?

RQ2: In relation to the environmental dimension, how do the offerings of LSPs and the requirements of shippers align?

RQ3: What are the critical success factors and/or inhibitors to success with regard to environmental alignment between LSPs and shippers?

The article is organised as follows. The section following this introduction describes the literature review that informed the identification of three research questions. Section 3 
describes the research design adopted to answer these questions. In section 4 the results emerging from the case study investigation are analysed and discussed. Section 5 outlines the key conclusions, with a focus on the research and managerial implications emerging from the study.

\section{Literature and Framework}

This section documents the authors' review of the relevant literature in relation to green logistics, GSCM and stakeholder theory, and describes how this literature informed the development of their three research questions (RQs). These RQs provide a focus for the subsequent discussion and conceptualisation. Sections 2.1, 2.2 and 2.3 respectively deal with the three interconnected dimensions which form the focus of this study, i.e. levels of awareness, practices in terms of customer requirements and provider offerings, and, critical success factors and inhibitors to success. Section 2.4 provides a summary of relevant themes from a second body of literature, stakeholder theory, as well as examples of its previous use in green logistics and GSCM research. Based on this, three guiding principles of stakeholder theory are identified as an appropriate prism through which the research questions can be analysed.

\subsection{Awareness relating to green logistics practices}

In this article the focus is on environmental aspects of the provision and purchasing of logistics services. In this context, the body of green logistics knowledge in the extant literature - effectively a subset of GSCM (McKinnon 2015) - offers relevant insights into both shippers' and LSPs' corporate strategic decision-making processes, albeit that each side is dealt with in isolation in most literature.

On the LSP side, there is evidence of growing pressure to become greener (Lieb and Lieb, 2010; Isaksson and Björklund, 2010; Gammelgaard and Prockl, 2012; Oberhofer and Dieplinger, 2014). The LSP industry has over a number of decades gone through a transformation from single-service transport provision towards provision of a wider range of services (Ashenbaum et al., 2005; Langley, 2017). The environmental awareness levels in LSPs positively influence the adoption of green actions and strategies (Bloemhof et al., 2015; Salhieh and Abushaikha, 2016). This is mirrored in statements from LSPs where an increasing awareness of climate issues among citizens is an important trigger for greening their activities and offerings (for example, "In future, for most companies, long-term success will be strongly linked to more sustainable business concepts" (DHL, 2010, p 15)).

On the shipper side, however, awareness of environmental issues also appears to have grown, which can be seen through the way buyers consider the environmental dimension. An early investigation by Murphy and Poist (2003) indicated a relatively high overall level of awareness of environmental issues among US and European manufacturing and trading firms. One indicator of a growing awareness among shippers is the extent to which environmental supplier evaluations are used (Zsidesin and Siferd, 2011). Tools for such evaluations are important (Large et al., 2011), but rare (Foerstl et al., 2010; Tundys and Wisniewski, 2018). However, the level of shipper concern for environmental issues declines substantially when purchasing transport and logistics services (Evangelista et al., 2012). Various studies position environmental issues - among shippers' requirements behind price, reliability and transport quality (Lammgård and Andersson, 2014) behind 
load factor (Kellner and Igl, 2015) and behind space utilisation and location of facilities (McKinnon, 2014).

Among the few studies that explore both LSP and shipper sides, Lieb and Lieb (2010) noted a growing acknowledgement of the importance of environmental sustainability among LSPs, this was not evident across the wider supply chain. Björklund (2011) argued that shippers' requirements of their LSPs may be limited or reduced by a relatively low level of environmental awareness among LSPs. This illustrates the interlinkage between providing and buying logistics and transport services. From a GSCM perspective this underlines not only the importance but also the relative lack of research into alignment between LSPs and their customers.

Although awareness of the importance of green issues appears to be growing both among LSPs and - albeit at a limited pace - their customers, the actual implementation of green initiatives lags behind. One potential explanation is that there is a low degree of alignment between LSPs and their customers regarding how they prioritize among the variety of green issues with respect to logistics services (as suggested by, for example: Martinsen, 2014; Ellram and Golicic, 2015; Sallnäs, 2016). While awareness of the environmental dimension does not per se mean that green activities actually take place, a certain level of awareness would appear to be an important prerequisite for such activities. The specific gaps in current understanding of the issues highlighted above lead to the development of the following research question:

RQ1: In relation to the environmental dimension, how do levels of awareness align between LSPs and shippers?

\subsection{Adoption of green logistics practices}

Use of an appropriate taxonomy is helpful in capturing the plethora of possible green logistics initiatives. From a GSCM perspective, Eltayeb and Zailani (2009) suggested a general classification of green supply chain initiatives into the three categories: ecodesign or design for the environment; green purchasing; and, reverse logistics. This categorisation relates directly to the buyer or purchasing side and not directly to the provision side. Most of the literature on GSCM has focused on studying a single function or activity rather than looking at the entire supply chain (Rao and Holt, 2005). For example, transportation has been the focus of many previous research studies due to its significant contribution to greenhouse gas emissions, while green logistics initiatives beyond transport have received less attention (see, for example: Marchant, 2010). As pointed out by Srivastava (2007), there is a need to implement and integrate a set of green measures comprising transport and non-transport focused initiatives in order to span a wider range of supply chain activities.

On the LSP side, the need for GSCM research to reach beyond operational transport issues is also relevant. LSPs have gradually transformed the scope of their service offerings, shifting from providing a single activity (i.e. transport) toward a wider range of services (Langley, 2017). Therefore, they are in a position to adopt an appropriate combination of green transport and non-transport related initiatives. In response to this, Evangelista et al. (2017) proposed a classification of green actions distinguished between those predominantly affecting the LSP company internally; and, those with a main impact at a wider supply chain level. Weijers et al. (2012), presented a range of potentially useful mechanisms for LSPs going greener: new driving style; buying new and less polluting 
vehicles; reducing energy consumption in warehouses; controlling tyre pressure; monitoring driving speed; using alternative modes of transportation; using more biofuels; improving loading capacity; buying electric vehicles; increasing efficiency; reducing distances driven; and, avoiding empty hauls.

Turning to the shipper side, research into green purchasing in its early phases focussed mainly on product suppliers. An example of research into product purchasing is Yen and Yen (2012), who highlighted the importance of top management commitment to green purchasing. As a result of a growing level of awareness of the environmental impact of transport, the focus on purchasing of logistics and transport services has sharpened; however, this area has received relatively little attention in the literature compared to other green purchasing areas (Björklund, 2011; Walker et al., 2012). Environmental demands when purchasing transport and logistics services include those of technological nature (e.g. transport mode and engine standard); of efficiency management nature (e.g. logistics system design and transport management); and various standards (such as ISO 14001) (see for example Martinsen and Huge-Brodin, 2014).

While Wolf and Seuring (2010) focussed on the procurement and supply of green transport and logistics services, they stress the lack of alignment between buyers and LSPs. The paper of Kudla and Klaas-Wissing (2012) analysed the misalignment of stimuli and responses about the green actions undertaken by LSPs and shippers. They found that shippers' stimuli (e.g. selection criteria and incentives) are at an early stage, while LSP initiatives have a stronger environmental focus. Partly in response to this misalignment, Martinsen and Huge-Brodin (2014) adopted a dual perspective in focusing on environmental practices, i.e. one which examines both LSPs and shippers and thus provides richer insights into the phenomena under investigation. The current research builds on this dual approach by focussing specifically on the levels of alignment - or lack thereof - between shipper needs and LSP offerings.

There is differing evidence in relation to what green logistics services are actually offered and how effectively this responds to shipper demand. A previous survey of the Swedish logistics market indicated that LSPs offerings of green services exceed the shippers' requirements (Martinsen and Björklund, 2012). Although the survey study was performed in Sweden only, the general literature overview suggests that this might be the case more widely (see, for example: Ellram and Golicic, 2015; Jørsfeldt et al., 2016). Sallnäs and Huge-Brodin (2018) further suggest that shippers' requirements and LSPs' offerings in specific relationships tend to align over time but that this alignment may have positive as well as negative impact on the actual environmental performance of the respective actors. Hence, the levels of alignment between LSPs' offerings and customers' requirements are worthy of investigation in the context of the wider perspective taken in this article. This leads to the second research question:

RQ2: In relation to the environmental dimension, how do the offerings of LSPs and the requirements of shippers align?

\subsection{Critical success factors and inhibitors to success for adopting green logistics practices}

In the quest to understand what influences the development of green logistics services, the extant literature offers a range of suggestions in relation to those factors that appear to be critical to success (i.e. the critical success factors or CSFs), as well as in relation to 
factors that appear to inhibit success. Both the CSFs and the inhibitors to success naturally include many of the stakeholders alluded to in the introductory section.

On the LSP side, a number of driving forces have affected the industry, thus presenting new strategic challenges and opportunities. LSPs have largely had to face two different challenges: first, their need to maintain or decrease cost levels in an environment of volatile fuel prices and increasing taxation (van Hoek and Johnson, 2010); and, second, various types of influence emanating from the customer side (Foster et al., 2000). In relation to the shipper side, Carter et al. (2000) demonstrated that more environmentally orientated purchasing practices can lead both to increased net income and lower costs, thus promoting improved overall firm performance.

Research suggests that several factors, including regulatory compliance, customer influence and risk minimisation (Walker et al., 2008), have encouraged the adoption of green purchasing practices. According to Yen and Yen (2012) the adoption of environmentally sustainable purchasing practices is associated with the levels of top management commitment, as well as with various measures of integration between the buying firm and its customers. But the same study also reveals that legal factors play a relatively insignificant role in the adoption of green purchasing. A number of studies have been conducted on the influence of customers and other stakeholders on the adoption of green initiatives by LSPs. Most of these studies (see, for example: Wong and Fryxell, 2004; Björklund, 2011; Rossi et al., 2013) indicate that factors relating to management and customers are the strongest influences, whereas other papers (see, for example: Pålsson and Kovács, 2014; Perotti et al., 2015) have found lower levels of influence from these pressures. Finally, Sallnäs and Huge-Brodin (2018) conclude that high environmental competence levels in LSPs may encourage shippers to engage in developing green logistics services, with the primary purpose of accessing knowledge and competence for themselves.

Previous research aimed at the identification of the CSFs and inhibitors to success has been performed to a greater extent on the shipper side than on the LSP side. Nonetheless, some studies (see, for example: Lin and Ho, 2011; Ho and Lin, 2012) found that the adoption of green practices by LSPs is obstructed by business uncertainty rather than by specific customer pressures. On the other hand, the study of Perotti et al. (2015) indicates that the relatively low level of interest in green products and services by customers and suppliers represents the main barrier to LSP adoption of green initiatives. Some researchers suggest that a possible inhibitor to the development of greener logistics services is the low degree of alignment between LSPs and their customers, which spans a wide range of areas (see, for example: Eng-Larsson, 2014; Isaksson, 2014; Martinsen, 2014). This is not surprising given the different roles that LSPs and their customers play in the supply chain, as well as the attendant differences that pertain in relation to strategic priorities, business models, corporate cultures, operational processes and myriad other issues (see, for example: Huge-Brodin et al. 2013). While a considerable body of literature exists in relation to the factors that influence the adoption of more environmentally sustainable logistics, there is a dearth of evidence in relation to the factors that specifically impact alignment between LSPs and their customers. These considerations gave rise to the development of the final research question:

RQ3: What are the critical success factors and/or inhibitors to success with regard to environmental alignment between LSPs and shippers? 


\subsection{Stakeholder theory}

Freeman introduced the stakeholder model in 1984 (see Figure 1). It acknowledges that a multitude of actors - i.e. stakeholders - have an interest in any corporation. These include, but are not limited to, a firm's customers, suppliers and competitors. According to Freeman (1984), a stakeholder is "..any group or individual who can affect or be affected by the achievements of the firm's objectives" (p. 25). Stakeholder theory is basically about how a company should manage its business while considering the interests of its various stakeholders. Further, the stakeholder model (or theory) has the strength of considering not only business aspects or ethical issues in singularity, but offers a way of analysing a multitude of aspects in a more holistic manner.

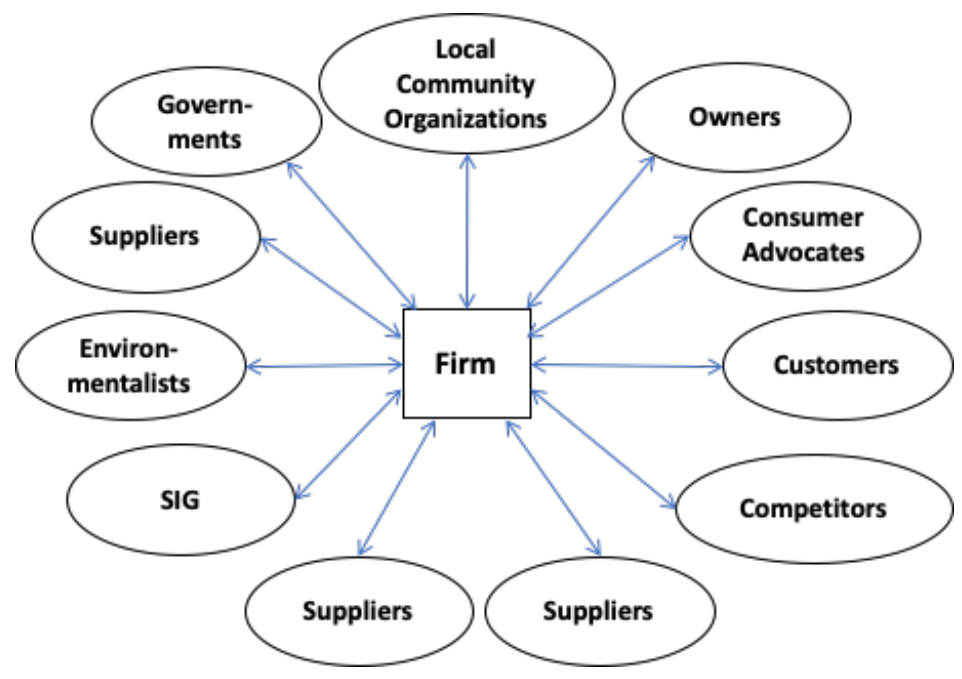

Figure 1: The original Stakeholder model (Freeman 1984, p. 25)

Stakeholder theory has been applied previously in research relating to green logistics and GSCM. Sarkis et al. (2011) argued that stakeholder theory may support the understanding of the multitude of actors that influence, and are influenced by, any companies' externalities, such as environmental impact: "...internal and external groups will influence organisational practices. Environmental externalities may be internalized through these stakeholder pressures within and between supply chain members." (p. 9). In particular, they point to research opportunities in applying stakeholder theory to innovation diffusion and various other management practices. The adoption of green logistics practices is an example of innovation diffusion. In this article, the focus is on the role of LSP/shipper environmental alignment, acknowledging the influence of other stakeholders.

With manufacturing firms in focus, Vachon and Klassen (2007) studied the effects of focal actors' integration with suppliers and customers, and their findings suggest that more integration work can be found in strategic collaboration with suppliers than with customers. Vachon (2007) further concluded that environmentally related collaboration with suppliers more often results in investment in environmentally related technology than other initiatives, while customer collaborations more typically involve investment in management systems. Relating their findings to this article, either the LSP or the shipper can be treated as the focal actor. 
Different types of stakeholder are of various levels of importance and play different roles for companies (Freeman, 1984). Post et al. (2002) claimed that the first stakeholders an actor should consider are those that are part of a company's resource base and directly important to the success of the company; secondly, stakeholders belonging to the same industry structure; and, thirdly, those stakeholders that are part of a political arena. Kirchoff et al (2011) refer to primary stakeholders (e.g. investors, customers and employees) and secondary stakeholders (e.g. suppliers and regulatory authorities). Fassin (2009) makes a distinction between three stakeholder types: stake watchers (pressure groups); stake keepers (regulators); and stakeholders (interacting with the focal firm). Finally, Freeman et al. (2010) present a stakeholder model that distinguishes between primary and secondary stakeholders but in a slightly different way to Kirchoff et al. (2011) - see Figure 2. Their split is dependent on the degree to which the firm creates value for the different stakeholder groups.

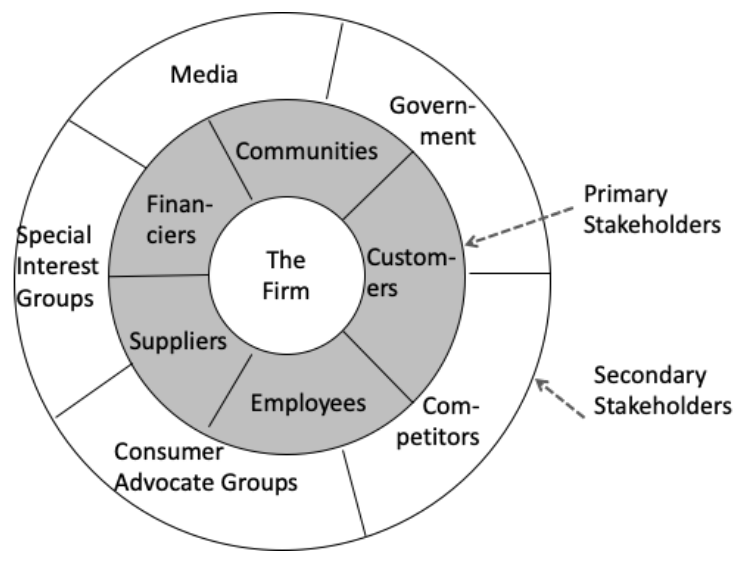

Figure 2: Creating value for stakeholders. (Based on Figure 1.2, p 24, Freeman et al. 2010).

The importance of stakeholders and their interest to any focal firm cannot be considered in isolation from each other. Post et al. (2002) concluded that the interests of various stakeholder groups can be mutual and thus overlapping, meaning that the influence from different stakeholders adds up to a stronger overall influence on the focal actor. This underlines the importance of taking a multi-stakeholder perspective. Wong and Fryxell (2004) suggested that the characteristics of the focal firm itself also matters in order to decide the influence from a specific stakeholder group. In their investigation, the influence of legislative authorities was found to be higher among larger firms, and lower among smaller firms. This opens up the question of how company characteristics (e.g. size) moderates the influence that stakeholder groups can have on firms in similar settings.

The authors henceforth see LSPs and shippers as: i) actors in different positions along the supply chain; and, ii) stakeholders of each other. Hence, the suggestions above regarding the various impacts of stakeholders will be used to develop a better understanding of the LSP-shipper environmental alignment. This is primarily in line with the "buyer-supplier dyad" level of focus of Walker et al. (2012), with the "supply chain/network" and "market/society/stakeholders/NGOs" levels addressed to an extent as a result of the use of stakeholder theory. Using stakeholder theory enables an extension beyond the purely dyadic level, thereby acknowledging the role of a wider group of actors (Miemczyk et al., 2012). 
The three research questions developed above will be addressed through the lens of stakeholder theory. With the original stakeholder model as a starting point, it is possible to relate LSPs and their customers to each other (see Figure 3). The aim of the figure is to indicate influences from different types of stakeholder groups rather than actual relationships between specific actors, while keeping the characterisation of stakeholders as primary and secondary (as in figure 2) open. In doing so, we aim to widen the understanding of alignment between LSPs and shippers, and how the various stakeholder groups may influence the two company types in focus of this paper. The stakeholders in the figure are indicative of possible stakeholder groups.

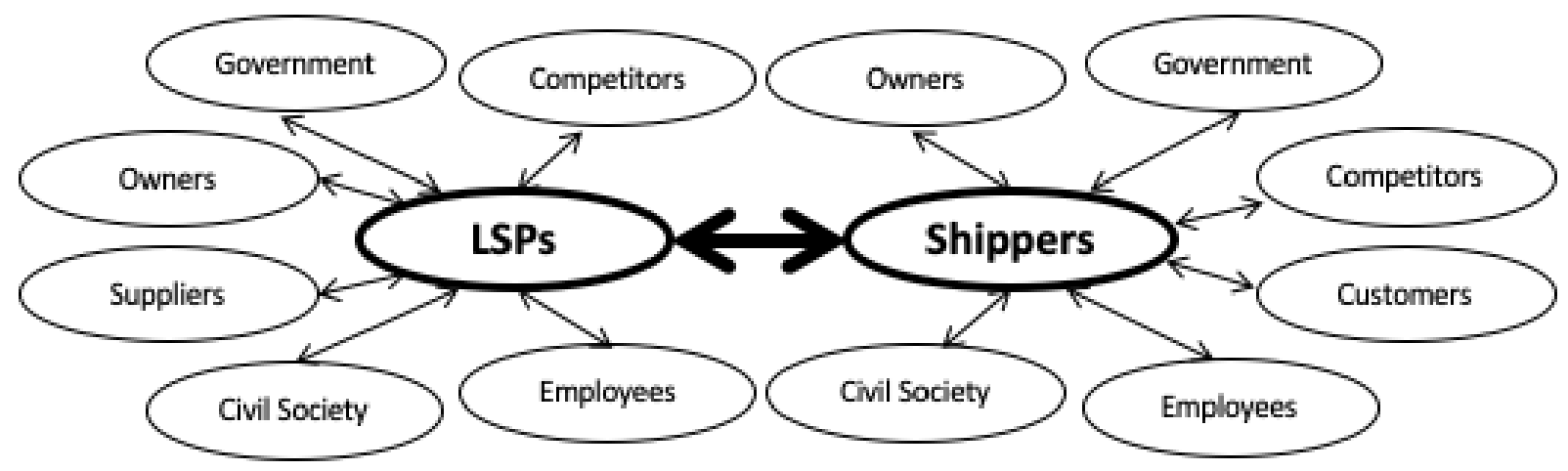

Figure 3: The original stakeholder model (Freeman, 1984) refined for this article.

This model provides a conceptual framework for that part of the analysis that seeks to explain the findings from the empirical evidence. This analysis will be structured according to the following three guiding principles:

- Primary stakeholders (e.g. customers) have higher influence on the focal firm and are considered before the firm's secondary stakeholders (e.g. suppliers) (Freeman et al. 2010; Kirchoff et al. 2011);

- The influences of multiple stakeholders can be overlapping, thus reinforcing an influence on the focal firm (Post et al. 2002); and,

- The characteristics of a focal firm (e.g. size) moderates the influences of other specific actor groups (e.g. legislative authorities) (Wong \& Fryxell 2004).

Data from the authors' case studies will be analysed to provide insights into the three RQs. These stakeholder theory guiding principles will then be applied in the search for a deeper understanding of the issues related to each RQ.

\section{Research Design}

In the first section, the overall research strategy is explained. The second section then presents the constituent elements of the research design, with section three then discussing issues of research quality.

\subsection{Overall research strategy}

As noted previously, the purpose of this article is to develop a better understanding of the nature of the alignment between LSPs and shippers regarding green logistics. The relative 
paucity of research into the phenomena to which the authors' three research questions (RQs) relate means that the current study is largely exploratory in nature. Indeed the nature of the RQs is such that they can probably never be answered entirely definitively. Thus, the main purpose of the questions is to provide a focus for the work and to ensure that the empirical research builds on the current understanding of the pertinent issues from the relevant extant literature.

The aim of the research is to contribute to conceptual development and understanding, rather than to empirical generalizability. The authors were also mindful of the advice of Croom et al. (2000) who advocated the "constant reflection of empirical against theoretical studies." (p.75), as well as of the work of Storey et al. (2006) who stated in relation to their case-based research design that, "This kind of dual theoretical and empirical approach is in tune with the point made by Croom et al. (2000)" (p. 763). Indeed, some of the principles of grounded theory (GT) methodology are in evidence here in that the approach adopted was an iterative (or recursive) one with data collection and analysis carried out in tandem, repeatedly referring back to each other, as well as to the relevant concepts from the extant literature.

The conceptual framework derived from stakeholder theory - in particular the three guiding principles described in section 2.4 - guided the authors' overall research design. The role of these guiding principles is as a prism through which the phenomena under investigation can be viewed, steering the analysis in a distinct direction. In essence, the role of the data in this article is to illustrate the discussion, as well as to inform the analysis.

\subsection{Research methodology}

The authors have selectively used data and results that directly correspond to the RQs from an ongoing long-term research project. In particular, the analysis of data from a range of case studies allowed the type of in-depth information required to address the RQs to be developed. The use of case studies in exploratory research in logistics has increased in recent years and is in line with the many earlier calls in the literature for their use (see, for example: Gammelgaard, 2003; Juga, 2003). The exploratory nature of the research means that the focus in selecting case firms was to generate a breadth of perspectives from a range of sectors (i.e. rather than empirical generalisability). With this in mind, a purposive sampling strategy was adopted (see, for example: Bryman and Bell, 2011).

For this article eight LSPs were selected from across the three countries in the study (four based in Sweden, two in Italy and two in Ireland). A common feature amongst all firms was their demonstrable commitment to improving the environmental sustainability of their activities in the long term. To generate the required breadth of perspectives, the chosen LSPs represent providers of a variety of transport and logistics services (e.g. road haulage, freight forwarding and contract logistics). They also represent a range in terms of size and geographical reach (see table 1). 
Table 1: Company profiles of the LSPs.

\begin{tabular}{|c|c|c|c|c|c|c|c|c|}
\hline \multicolumn{9}{|c|}{ LSP COMPANY PROFILES } \\
\hline & SWE A & SWE B & SWE C & SWE D & ITA A & ITA B & IRL A & IRL B \\
\hline $\begin{array}{l}\text { Service } \\
\text { offering }\end{array}$ & $\begin{array}{l}\text { Diverse road } \\
\text { transport } \\
\text { services, } \\
\text { including } \\
\text { distribution } \\
\text { and heavy } \\
\text { transportation }\end{array}$ & $\begin{array}{l}\text { Diverse road } \\
\text { transport } \\
\text { services, } \\
\text { including } \\
\text { distribution } \\
\text { and heavy } \\
\text { transportation }\end{array}$ & $\begin{array}{l}\text { Air and } \\
\text { ocean } \\
\text { freight } \\
\text { services }\end{array}$ & $\begin{array}{l}\text { Wide range } \\
\text { of transport } \\
\text { and } \\
\text { logistics } \\
\text { services, all } \\
\text { transport } \\
\text { modes }\end{array}$ & $\begin{array}{l}\text { Logistics } \\
\text { services; ware- } \\
\text { housing, } \\
\text { inbound \& out- } \\
\text { bound logistics } \\
\text { \& distribution }\end{array}$ & $\begin{array}{l}\text { Transport } \\
\text { services (rail } \\
\text { and sea), } \\
\text { various } \\
\text { logistics } \\
\text { services }\end{array}$ & $\begin{array}{l}\text { Contract } \\
\text { logistics } \\
\text { and freight } \\
\text { forwarding }\end{array}$ & $\begin{array}{l}\text { Wide range } \\
\text { of transport } \\
\text { and } \\
\text { logistics } \\
\text { services, all } \\
\text { modes }\end{array}$ \\
\hline $\begin{array}{l}\text { Geo- } \\
\text { graphical } \\
\text { reach }\end{array}$ & Local & Regional & $\begin{array}{l}\text { Inter- } \\
\text { national }\end{array}$ & $\begin{array}{l}\text { Inter- } \\
\text { national }\end{array}$ & Inter-national & $\begin{array}{l}\text { Inter- } \\
\text { national }\end{array}$ & National & $\begin{array}{l}\text { Inter- } \\
\text { national }\end{array}$ \\
\hline Size & Small & Small & Large & Large & Small & Large & Small & Large \\
\hline
\end{tabular}

On the buyer side, six consumer product companies with a requirement for logistics services were selected from across the three countries (one based in Sweden, three in Italy and two in Ireland). A common feature amongst all firms was a recognition of the critical role of logistics in overall firm performance. To generate the required breadth of perspectives, the chosen shippers represent suppliers of a range of product types (e.g. food, electronics and leisurewear) of varying sizes and serving a variety of geographical markets (see table 2).

Table 2: Company profiles of the shippers.

\begin{tabular}{|c|c|c|c|c|c|c|}
\hline \multicolumn{7}{|c|}{ BUYER COMPANY PROFILES } \\
\hline & SWE1 & ITA1 & ITA2 & ITA3 & IRL1 & IRL2 \\
\hline $\begin{array}{l}\text { Type of } \\
\text { product }\end{array}$ & $\begin{array}{l}\text { Sports and } \\
\text { leisurewear, } \\
\text { sports } \\
\text { equipment }\end{array}$ & $\begin{array}{l}\text { Coffee for retail } \\
\text { outlets }\end{array}$ & $\begin{array}{l}\text { Functional products } \\
\text { and food integrators }\end{array}$ & Frozen food & Consumer foods & Electronics \\
\hline $\begin{array}{l}\text { Company } \\
\text { system } \\
\text { description }\end{array}$ & $\begin{array}{l}\text { Retail chain: } \\
\text { global supply, } \\
\text { distribution } \\
\text { centre, over } 100 \\
\text { outlets }\end{array}$ & $\begin{array}{l}\text { Coffee makers } \\
\text { controlling the } \\
\text { downstream SC } \\
\text { (mainly bars) } \\
\text { through } 100 \\
\text { sale agents }\end{array}$ & $\begin{array}{l}\text { Design and } \\
\text { marketing of } \\
\text { product and } \\
\text { coordination of } \\
\text { outsourced } \\
\text { manufacturing and } \\
\text { distribution channels }\end{array}$ & $\begin{array}{l}\text { Product } \\
\text { processing. } \\
\text { Logistics and } \\
\text { merchandising } \\
\text { outsourced but } \\
\text { controlled by } \\
\text { internal staff }\end{array}$ & $\begin{array}{l}\text { Supply to } \\
\text { factories and } \\
\text { distribution } \\
\text { centres for large } \\
\text { retail and direct } \\
\text { to store for } \\
\text { smaller } \\
\text { customers }\end{array}$ & $\begin{array}{l}\text { Regional } \\
\text { distribution centre } \\
\text { supplying } \\
\text { customers }\end{array}$ \\
\hline $\begin{array}{l}\text { Geo- } \\
\text { graphical } \\
\text { market }\end{array}$ & $\begin{array}{l}\text { Nordic } \\
\text { countries }\end{array}$ & $\begin{array}{l}\text { Domestic }(90 \% \\
\text { approximately) } \\
\text { and foreign } \\
(10 \% \\
\text { approximately) }\end{array}$ & Domestic & Domestic & $\begin{array}{l}\text { Britain and } \\
\text { Ireland (some in } \\
\text { continental } \\
\text { Europe) }\end{array}$ & $\begin{array}{l}\text { Europe, Middle- } \\
\text { East and Africa } \\
\text { (EMEA) }\end{array}$ \\
\hline Size & Large & Small & Micro & Large & Large & Large \\
\hline
\end{tabular}

Company data was collected through in-depth semi-structured interviews with carefully identified key informants who have managerial responsibility for the issues under investigation. All interviews were recorded and transcribed. This interview data was supplemented with information from company websites, reports and other internal documentation.

Among the relatively small number of dual-sided studies that have been undertaken on this topic, few take a purely relational perspective, i.e. they study both sides of existing 
relationships (see for example Vieira et al., 2016 and Ellram and Golicic, 2015). This study takes the approach of investigating carefully selected actors and their perceptions of "the other side", without focusing on specific dyadic relationships (as done by, for example: Martinsen and Huge-Brodin, 2014). The approach used in this paper involves the selection of appropriate examples from each category (i.e. LSPs and shippers) and that are not constrained by specific relationship boundaries. Furthermore, the analysis and results are, as a consequence, restricted to discussion of a conceptual nature on alignment between the categories, which is well in line with the paper's overall exploratory approach.

The analysis procedure was developed iteratively and in discussions among the authors. Different approaches were discussed and tested, and the final version is presented in this article. As well as being guided by the conceptual framework, the authors followed the suggestion of Easterby-Smith et al. (2008) who describe two approaches to the analysis of this type of largely qualitative data: content analysis and grounded analysis. The former involves interrogating the data for ideas and constructs that have been considered in advance; the latter essentially involves letting the data "speak for itself" thus guiding the researcher towards an understanding of the data. In this way, the authors' analysis involves an effective combination of the two approaches, thus integrating the strengths and mitigating the shortcomings of the two alternatives.

Specifically, the analysis is structured around the three research questions (RQs). First, an initial response to each RQ is formulated based on the authors' analysis of their data. This initial response is then refined by applying the three guiding principles developed from stakeholder theory as described in section 2.4.

\subsection{Research quality}

The four qualitative criteria recommended by Lincoln and Guba (1985) - credibility, transferability, dependability and confirmability - have been adopted by the authors to ensure the quality of this research. A particular focus is on validity and reliability. The credibility criterion involves establishing that the results of qualitative research are credible from the perspective of the participants in the research. This credibility criterion was addressed largely by inviting interviewees to comment on the authors' summaries of their data. This helps to ensure that the research results are credible from a key informant perspective. As noted above, the relatively small sample used in the current exploratory research is not intended to be definitive in terms of empirical generalisability and transferability is difficult in this context. However, use of semi-structured interviews with carefully chosen key informants in a range of different LSP and shipper firms is designed to enable some potentially useful initial insights into the three RQs to be developed inductively. Our use of stakeholder theory then aims to refine these initial insights. Dependability emphasizes the need for researchers to account for the changing contexts within which research occurs. In this regard, the authors comprehensively documented the whole research process - including the critical semi-structured interviews - from initial design through data collection, and further through to data analysis. Confirmability refers to the degree to which the results could be confirmed by others. Our detailed description of the chosen research design should allow future work to build directly on the findings of this research, including through the use a combined inductive/deductive approach based on methodological triangulation. 


\section{Findings}

The overall aim of the analysis is to explore the alignment between LSPs and shippers with respect to environmental issues, and the analysis is structured around the three research questions (RQs). For each RQ, relevant empirical data are first presented in tabular format. The associated text contains selected direct quotes from the interviews which highlight the salient issues raised by the key informants. These data are then analysed using the combination of content and grounded analysis explained in section 3.2. This allows an initial response to each RQ to be formulated. This initial response is then refined by applying the three guiding principles. As described in section 2.4, these principles were developed by the authors based on their refined stakeholder theory model (see Figure 3).

\subsection{Alignment between levels of awareness}

The level of awareness of environmental issues among informants was measured in a variety of ways. The LSPs were asked to relate the importance of green issues to their strategic development. The extent to which authority was devolved was also used as an indication of priority. The shippers were asked about the overall strategic importance of environmental issues, as well as about their environmental perspective when purchasing transport and logistics services specifically. This provides insights beyond the basic levels of awareness explicitly communicated by the companies. As described in greater depth by Martinsen and Björklund (2012) perception is important in the context of its role in shaping collaboration and alignment. Table 3 and table 4 summarise these for the LSPs and the shippers respectively.

Table 3: LSPs' awareness of environmental importance

\begin{tabular}{|c|c|c|c|c|c|c|c|}
\hline SWE A & SWE B & SWE C & SWE D & ITA A & ITA B & IRL A & IRL B \\
\hline \multicolumn{8}{|c|}{ LSPS' PRIORITISATION OF ENVIRONMENTAL ASPECT } \\
\hline $\begin{array}{l}\text { Long and short- } \\
\text { term }\end{array}$ & $\begin{array}{l}\text { Long and } \\
\text { short-term }\end{array}$ & $\begin{array}{l}\text { Differs } \\
\text { between } \\
\text { business units }\end{array}$ & $\begin{array}{l}\text { Long-term, } \\
\text { strategic }\end{array}$ & $\begin{array}{l}\text { Long-term, } \\
\text { strategic }\end{array}$ & $\begin{array}{l}\text { Long-term, } \\
\text { but implicit }\end{array}$ & $\begin{array}{l}\text { Non- } \\
\text { strategic } \\
\text { issue }\end{array}$ & $\begin{array}{l}\text { Strategic } \\
\text { priority }\end{array}$ \\
\hline \multicolumn{8}{|c|}{ LSPS' DISTRIBUTION OF RESPONSIBILITIES FOR ENVIRONMENTAL CONCERN } \\
\hline $\begin{array}{l}2 \text { FTE* with } \\
\text { green respon- } \\
\text { sibility (spread } \\
\text { among more } \\
\text { people). Support } \\
\text { function }\end{array}$ & $\begin{array}{l}3 \text { dedicated } \\
\text { FTE for } \\
\text { environment } \\
\text {, quality and } \\
\text { education. } \\
\text { Support } \\
\text { function }\end{array}$ & $\begin{array}{l}4 \text { FTE in sup- } \\
\text { port function. } \\
7 \text { key persons } \\
\text { working } 1 / 3 \text { of } \\
\text { full-time } \\
\text { employees }\end{array}$ & $\begin{array}{l}5-6 \text { FTE, } 1 \\
\text { dedicated, } \\
\text { the rest as } \\
\text { part of their } \\
\text { ordinary } \\
\text { duties }\end{array}$ & $\begin{array}{l}\text { Multiple } \\
\text { functions } \\
\text { involved, } \\
\text { Operations } \\
\text { Manager as } \\
\text { key person }\end{array}$ & $\begin{array}{l}\text { Green team, } \\
\text { involving } 3 \\
\text { employees } \\
\text { managed by } \\
\text { Operations/ } \\
\text { Quality } \\
\text { Manager }\end{array}$ & $\begin{array}{l}\text { No people } \\
\text { involved }\end{array}$ & $\begin{array}{l}\text { Cross- } \\
\text { functional } \\
\text { organi- } \\
\text { sation }\end{array}$ \\
\hline
\end{tabular}

*FTE = Full-time equivalent employees

As shown in table 3, with few exceptions, LSPs stated that their prioritisation of environmental issues is long-term and/or of a strategic nature. For example, ITA B stated that "We believe that a substantial level of environmental consciousness is critical for the future of our company. For this reason, environmental issues have a high priority in the company strategy". These findings largely reflect the growing concern among LSPs as captured in previous research (see, for example: Lieb and Lieb, 2010; Isaksson and Björklund, 2010; Gammelgaard and Prockl, 2012). In addition, most LSPs were able to pinpoint where in the organisation the responsibility for environmental issues is placed, and often also accompanied this with a figure capturing the scale and/or budget for that 
responsibility - see table 3. The way environmental responsibility is organised differs widely among the LSPs, which is also in line with the findings of Isaksson and Huge-Brodin (2013). In SWE B, for example, the environmental work was the responsibility of all employees: "We want to educate our employees so they can support our customers; everyone in the organisation should know where we stand when it comes to sustainability issues". Overall, the LSPs both state and demonstrate long-term and concrete awareness of environmental issues.

Table 4: Shippers' awareness of environmental importance

\begin{tabular}{|l|l|l|l|l|l|}
\hline \multicolumn{1}{|c|}{ SWE1 } & \multicolumn{1}{|c|}{ ITA1 } & \multicolumn{1}{c|}{ ITA2 } & IRL1 & IRL2 \\
\hline \multicolumn{5}{|c|}{ SHIPPERS' STRATEGIC ENVIRONMENTAL CONCERN } \\
\hline $\begin{array}{l}\text { Of growing } \\
\text { concern, but not } \\
\text { part of the core } \\
\text { business }\end{array}$ & $\begin{array}{l}\text { Important but } \\
\text { does not play } \\
\text { a key role in } \\
\text { company } \\
\text { strategy }\end{array}$ & $\begin{array}{l}\text { Important role } \\
\text { that drives key } \\
\text { company's } \\
\text { decisions }\end{array}$ & $\begin{array}{l}\text { Part of the } \\
\text { company mission } \\
\text { and it is seen as a } \\
\text { business } \\
\text { opportunity }\end{array}$ & $\begin{array}{l}\text { High priority but } \\
\text { reduced due to } \\
\text { business } \\
\text { downturn }\end{array}$ & $\begin{array}{l}\text { Very high priority } \\
\text { driven by the } \\
\text { managing director }\end{array}$ \\
\hline SHIPPERS' ENVIRONMENTAL CONCERN IN PURCHASING TRANSPORT AND LOGISTICS SERVICES
\end{tabular}

From the overview in table 4 it appears that all of the shippers acknowledge environmental issues as important, albeit to varying degrees. For some, the importance is growing but is still not a key decision criterion. As noted by ITA 1, "Environmental sustainability ... does not play a decisive role in guiding the company's strategy". For others, environmental issues are identified as being more crucial and of greater strategic importance. For example, ITA 2 stated that: "Our approach to sustainability has progressively involved all company functions...Environmental sustainability is, therefore, extremely important in guiding company decision-making process and an essential element of our corporate strategy". SWE 1 expressed a similar view: "On the corporate management level there is great awareness that sustainability not only concerns cost savings and risk minimization, but is also valuable in itself, and even more so in the future". This is in line with earlier research results that indicated high awareness levels among shipper companies (Murphy and Poist, 2003). However, in shippers' purchasing of transport and logistics services, environmental issues appear to be of lesser importance. Despite being acknowledged, the environmental performance of an LSP does not play a critical role in business decision making. For example, ITA 3 stated that "Our company adopts an approach that does not consider environmental aspects a priority when buying logistics services. The most important selection criteria for us are cost, quality and reliability". In a similar vein, IRL 2 attributed a low level of priority to environmental issues when buying logistics services with a focus on "contractual and transactional issues". This is despite the fact that the company attributes a "very high priority to environmental issues at corporate level, driven by the managing director". This picture essentially reinforces the findings of previous research (see, for example: Björklund, 2011). 
RQ1 reads: In relation to the environmental dimension, how do levels of awareness align between LSPs and shippers? Based on the foregoing, an appropriate response to RQ1 is: In relation to the environmental dimension, the levels of awareness between LSPs and shippers align more at the general company level than specifically in relation to the task of providing and acquiring transport and logistics services.

The stakeholder theory guiding principles previously developed by the authors based on their refined stakeholder theory model (see Figure 3) were then followed in the search for a deeper understanding of the issues related to RQ1.

The LSPs and the shippers have different levels of importance for each other. Following Freeman et al. (2010) the shippers should consider the LSPs as primary stakeholders, and vice versa. In line with this, environmental awareness should align to a higher extent than the data indicate. On the other hand, if the way Kirchhoff et al (2011) describe the stakeholders vis-à-vis each other is considered, the customer to a firm is considered a primary stakeholder, while a supplier is considered a secondary stakeholder. Hence, an LSP would have less influence on a shipper than vice-versa - a scenario which the research findings support.

Considering the effects from a multitude of actors, the relatively high levels of awareness among the LSPs can be explained by a range of overlapping interests. These include legislation and regulations setting limits and standards that drive greener transport, and technology vendors promoting their greener technology. Such compound drivers could together be seen as stronger than the relatively weak signals from the LSPs' customers (i.e. the shippers), thus contributing to the higher levels of awareness (compared with the overlapping and influences referred to by Post et al., 2002). From the shipper perspective, it could be argued that the strongest influence for greening transport and logistics services emanates from the LSPs, as customer pressure often lacks from the shippers themselves or their customers (see, for example: Björklund, 2011). In many ways this also reflects the core competencies of the firm types given their respective roles in the supply chain. In addition, legislative and regulatory measures are mainly aimed at LSPs and technology vendors rather than at shippers. Thus, the notion of Post et al. (2002) about overlapping influences can help explain the degree of awareness alignment between LSPs and shippers. A possible explanation of the authors' response to RQ1 is therefore: the overlapping interests from multiple stakeholders (i.e. other than the shippers) of the LSPS explains the relatively low degree of alignment between LSPs and shippers.

The cases in this study differ in size and scope of activities. However, the sample is too small to discern any clear patterns. Nonetheless, it appears that the larger LSPs demonstrate longer-term commitment while the smaller LSPs show more of a short-term focus. Thus, the smaller LSPs are aligned to a somewhat higher degree to the shippers regarding levels of awareness. A further insight into RQ1, therefore, might be: smaller LSPs are more aligned to customers than larger LSPS, with a possible explanation being that customer influence is stronger among smaller LSPs. This is in line with the earlier suggestion of Wong and Fryxell (2004) and of Nilsson et al. (2017).

\subsection{Alignment between offerings and requirements}

RQ2 refers to the alignment between LSPs' offerings and shippers' requirements. To measure actual levels of adoption, LSPs were asked which green initiatives were implemented in practice in terms of incorporation into their activities and customer 
offerings. The shippers were asked what was actually required when purchasing transport and logistics services. This approach is in line with that taken by Martinsen and Huge-Brodin (2014); however, in this research interviews with key informants from the case companies were used rather than relying purely on secondary data from websites. Table 5 and table 6 summarise the environmental initiatives being undertaken by the LSPs and the shippers respectively.

Table 5: LSPs' environmental initiatives

\begin{tabular}{|c|c|c|c|c|c|c|c|}
\hline SWE A & SWE B & SWE C & SWE D & ITA A & ITA B & IRL A & IRL B \\
\hline \multicolumn{8}{|c|}{ LSPS' GREEN INITIATIVES } \\
\hline $\begin{array}{l}\text { Eco-driving } \\
\mathrm{CO} 2 \\
\text { declaration } \\
\text { Better } \\
\text { alternative } \\
\text { offered }\end{array}$ & $\begin{array}{l}\mathrm{CO} 2 \\
\text { declarations } \\
\text { Internal } \\
\text { education } \\
\text { Partnerships } \\
\text { with } \\
\text { customers }\end{array}$ & $\begin{array}{l}\mathrm{CO} 2 \\
\text { declarations } \\
\text { Wide climate } \\
\text { protection } \\
\text { programmes }\end{array}$ & $\begin{array}{l}\text { Emission } \\
\text { calculations } \\
\text { Customised } \\
\text { solutions } \\
\text { Environmen } \\
\text { tally } \\
\text { friendly } \\
\text { vehicles }\end{array}$ & $\begin{array}{l}\text { Follow the } \\
\text { regulations } \\
\text { for vehicles } \\
\text { Intermodal } \\
\text { solutions }\end{array}$ & $\begin{array}{l}\text { Choice of } \\
\text { alternative } \\
\text { transport } \\
\text { modes }\end{array}$ & $\begin{array}{l}\text { Diverse } \\
\text { transport } \\
\text { initiatives }\end{array}$ & $\begin{array}{l}\text { Co- } \\
\text { ordinated } \\
\text { initiatives in } \\
\text { transport } \\
\text { Initiatives } \\
\text { beyond } \\
\text { transport }\end{array}$ \\
\hline
\end{tabular}

Regarding the initiatives taken, as presented in table 5, all LSPs address the transport component of their service offerings. Various emission calculations and initiatives relating to choice of vehicles and transport mode appear most commonly. Some initiatives stretch beyond transport to embrace various supply chain related initiatives (for example, network optimisation and coordination used by IRL B as part of its "co-ordinated initiatives in transport") all of which rely on extended use of technology. Many of the interviewed LSPs also described what they regarded as novel approaches to collaborative working. For example, SWE B stated that "We want to have close cooperation with our customers, be engaging, creative and solution-oriented and try new approaches and methods." while ITA A noted that "From the environmental point of view, our company is committed to working closely with our customer in order to improve relationships with them". IRL A also referred to collaboration with customers in the context of "diverse transport initiatives". The case findings further suggest a greater focus on measuring emissions among Swedish LSPs, and on intermodal transport among Italian LSPs.

Table 6: Shipper's environmental initiatives

\begin{tabular}{|c|c|c|c|c|c|}
\hline SWE1 & ITA1 & ITA2 & ITA3 & IRL1 & IRL2 \\
\hline \multicolumn{6}{|c|}{ MAIN ASPECTS ADDRESSED WHEN PURCHASING TRANSPORT AND LOGISTICS SERVICES } \\
\hline $\begin{array}{l}\text { Legal aspects, drivers' } \\
\text { behaviour, technology } \\
\text { standards, equipment } \\
\text { management, green } \\
\text { policy }\end{array}$ & $\begin{array}{l}\text { Green policy of } \\
\text { the logistics } \\
\text { providers and } \\
\text { actions to } \\
\text { reduce } \\
\text { emissions }\end{array}$ & $\begin{array}{l}\text { Green } \\
\text { certification and } \\
\text { use of recyclable } \\
\text { packaging }\end{array}$ & $\begin{array}{l}\text { No specific } \\
\text { aspects are } \\
\text { defined }\end{array}$ & $\begin{array}{l}\text { Minimum standards } \\
\text { (emissions) defined } \\
\text { (not very exacting) } \\
\text { and minimum legal } \\
\text { requirements met }\end{array}$ & $\begin{array}{l}\text { None beyond } \\
\text { compliance with } \\
\text { legal minimum } \\
\text { requirements }\end{array}$ \\
\hline
\end{tabular}

Table 6 reveals significantly less exacting requirements on the part of shippers in comparison to what LSPs' offerings encompass. SWE 1 puts it this way: "The efforts on our side have focused on increasing the fill-rate and making sure the right parcel reaches the right shop, and these efforts have decreased the number of shipments by 30\%". Similarly, 
ITA 3 stated that "No specific clauses are included in the logistics outsourcing contract to regulate aspects related to environmental sustainability". This is in line with the findings of Martinsen and Björklund (2012) and Martinsen and Huge-Brodin (2014), with the latter two studies undertaken in an exclusively Swedish context. The shippers in this sample mainly rely on legislation and standards, with few but varying exceptions. IRL 1 required that "not very exacting minimum legal requirements be met" with IRL 2 stating that "We have not implemented any environmental initiatives beyond those that are necessary to comply with minimum regulatory requirements". ITA 2 goes somewhat further, noting that "we generally require environmental certification (e.g. ISO 14001) of our logistics providers. In addition, we also require the use of a fleet of trucks with lower emission engines and the use of greener packaging for our products".

RQ2 reads: In relation to the environmental dimension, how do the offerings of LSPs and the requirements of shippers align? Based on the foregoing, an appropriate response to RQ2 is: In relation to the environmental dimension, LSPs' offerings and shippers' requirements are poorly aligned. More specifically, while shippers rely on standards and legislation, LSPs focus on demonstrating the environmental impact of transport with a view to adopting appropriate mitigation strategies.

The stakeholder theory guiding principles previously developed by the authors based on their refined stakeholder theory model (see Figure 3) were then followed in the search for a deeper understanding of the issues related to RQ2.

Based on the assumption that primary stakeholders have greater influence on a firm than secondary (Freeman et al. 2010; Kirchoff et al. 2011) it is perhaps somewhat surprising that the LSPs focus to a much higher degree than their customers on environmental aspects. One possible explanation relates to the shipper perspective. As their primary stakeholders are often consumers - or firms directly related to consumers - it can be expected that consumer requirements are reflected in the shippers' apparently rather rudimentary expectations of their LSPs. In line with Björklund (2011), the findings agree that the basic requirements on green logistics stem from consumer demand. Further, Martinsen and Huge-Brodin (2014) suggest that consumers are more interested in product characteristics than in their logistics partners' performance. A possible explanation of the authors' response to RQ2 is therefore: the alignment between LSPs' offerings and shippers' requirements depends highly on the requirements of the shippers' customers.

The notion of Post et al. (2002) that overlapping influences for change combine to create a stronger influence than from a single actor does not apply to this case; the requirements of shippers are less demanding than the actual offerings of LSPs. One possible explanation for this observation, which is in line with Martinsen and Björklund (2012), is that the LSPs' offerings and activities respond to their most demanding customers, and that the shippers in the sample represent market segments with relatively low expectations. Hence, the findings suggest, contrary to Post et al. (2002), that LSPs respond to environmental requirements from the most demanding shippers. A nuance to this reasoning is that, from a market perspective, it would be neither beneficial nor feasible for an LSP to align totally with its single most demanding customer; rather, the more demanding customers contribute to the raising of ambition levels of LSPs. A further insight into RQ2, therefore, might be: LSPs' offerings align with their most demanding customers' expectations. 


\subsection{Alignment with respect to critical success factors and inhibitors to success}

The third research question addresses critical success factors (CSFs) and inhibitors to success in the alignment between LSPs and shippers. The companies were first asked to make their own suggestions through open questions, and in addition a list of predefined factors of interest was presented and discussed with the respondents. Tables 7 and 8 provide overviews of LSPs' and shippers' most important CSFs and inhibitors.

Table 7: Critical success factors and inhibitors to success for LSPs.

\begin{tabular}{|c|c|c|c|c|c|c|c|}
\hline SWE A & SWE B & SWE C & SWE D & ITA A & ITA B & IRL A & IRL B \\
\hline \multicolumn{8}{|c|}{ CRITICAL SUCCESS FACTORS (CSFs) FOR GREENING LSPS } \\
\hline $\begin{array}{l}\text { Customers } \\
\text { Legislation } \\
\text { Management } \\
\text { influence } \\
\text { (Employee } \\
\text { influence) }\end{array}$ & $\begin{array}{l}\text { Customer } \\
\text { partnerships } \\
\text { Legislation } \\
\text { Management } \\
\text { influence } \\
\text { Employees }\end{array}$ & $\begin{array}{l}\text { Customers } \\
\text { Competitors } \\
\text { Management } \\
\text { influence } \\
\text { Employees }\end{array}$ & $\begin{array}{l}\text { Customers } \\
\text { Legislation } \\
\text { Management } \\
\text { influence } \\
\text { Employees }\end{array}$ & $\begin{array}{l}\text { (Customers) } \\
\text { Legislation } \\
\text { Management } \\
\text { influence } \\
\text { Employees }\end{array}$ & $\begin{array}{l}\text { Legislation } \\
\text { Management } \\
\text { influence } \\
\text { (Employees) }\end{array}$ & $\begin{array}{l}\text { (Legislation) } \\
\text { Management } \\
\text { influence }\end{array}$ & $\begin{array}{l}\text { Customers } \\
\text { (Legislation) } \\
\text { Management } \\
\text { influence } \\
\text { (Employees) }\end{array}$ \\
\hline \multicolumn{8}{|c|}{ INHIBITORS TO SUCCESS FOR GREENING LSPS } \\
\hline $\begin{array}{l}\text { Expensive } \\
\text { green } \\
\text { solutions } \\
\text { Lack of } \\
\text { customer } \\
\text { demand }\end{array}$ & $\begin{array}{l}\text { Only invest if } \\
\text { customer } \\
\text { supports } \\
\text { Lack of } \\
\text { customer } \\
\text { demand }\end{array}$ & $\begin{array}{l}\text { Hard to justify } \\
\text { investment } \\
\text { Lack of } \\
\text { customer } \\
\text { interest }\end{array}$ & $\begin{array}{l}\text { No clients } \\
\text { share in- } \\
\text { vestment } \\
\text { Lack of } \\
\text { consensus } \\
\text { regarding } \\
\text { solutions }\end{array}$ & $\begin{array}{l}\text { High costs \& } \\
\text { long pay-back } \\
\text { period } \\
\text { Lack of } \\
\text { customer } \\
\text { demand }\end{array}$ & $\begin{array}{l}\text { Low margins, } \\
\text { unsure income } \\
\text { Lack of } \\
\text { customer } \\
\text { interest }\end{array}$ & $\begin{array}{l}\text { High costs; } \\
\text { too long pay- } \\
\text { back period } \\
\text { Negative } \\
\text { impact on } \\
\text { customer SC }\end{array}$ & $\begin{array}{l}\text { High costs } \\
\text { Lack of } \\
\text { customer } \\
\text { demand }\end{array}$ \\
\hline
\end{tabular}

(CSFs of less importance but still with an influence are in brackets)

According to table 7, the CSF that appears as most important among the LSPs is the customer (i.e. the shippers); however, the fact that LSPs perceive a relatively low level of expectation from shippers constitutes an inhibitor. For example, ITA A stated that "Environmental impact is a critical problem for everyone including both customers and suppliers. However, no customer has ever put pressure on us or adopted any relevant measures to reduce this problem". IRL B referred to "low levels pressure from customers driven by legislation". This places shippers in a paradoxical position, where their influence as a stakeholder can best be described as ambiguous, in line with the findings of Sallnäs and Huge-Brodin (2018). The customer as an inhibitor is closely related to the financial situation, which is also considered to be an inhibitor to the greening of logistics services. For example, SWE A stated that "...the problem is that there are very few customers who value and put sustainability a a such a high level in order for you to even figure out a special price for these kinds of service offerings". Lack of interest from customers leads to a perception of lack of a potential return on investment in green initiatives on the LSP side. SWE D raised a critical question in this regard: "How do you charge customers for an environmental transport solution? We would like to work more with value-based pricing but the problem is understanding what it is really worth to customers". A CSF almost not mentioned is competition, which supports the view that there is a relatively low market demand for green logistics services.

Legislation could potentially be a strong driver for greener logistics services, but the current requirements of the various legislative authorities are considered to be low 
(described by IRL B as "not very demanding"). Some case companies pointed out that much of what is now a legislative or regulatory requirement has long been in place, and that such requirements do not stimulate change. For example, IRL A stated that "we are fully aware of what is required of us from a legal and regulatory point of view but these are all things that we are doing anyway". In other words, practice often leads rather than follows legal requirements. Nevertheless, some of the Swedish and Italian LSPs see legislation as a CSF but for different reasons. While the Swedish companies see legislation as facilitating fairer competition, the Italian LSPs recognise that regulation could drive the adoption of behaviours and practices in line with green logistics principles. Hence, legislation could potentially play a stronger role in the future.

Many of the LSPs particularly mention top level management influence as having a strong impact on the greening of logistics services (the Managing Director of IRL B, for example, described himself as "passionate about all things environmental"). Meanwhile, the importance of other employees varies among the LSPs, and in particular plays a relatively important role in Swedish LSPs. For example, SWE B stated that "We work a lot to increase personal responsibility and willingness to contribute to the whole company. I think this is a winning concept".

Table 8: Critical success factors and inhibitors to success for shippers to require green logistics services.

\begin{tabular}{|c|c|c|c|c|c|}
\hline SWE1 & ITA1 & ITA2 & ITA3 & IRL1 & IRL2 \\
\hline \multicolumn{6}{|c|}{ SHIPPERS' CRITICAL SUCCESS FACTORS (CSFs) } \\
\hline $\begin{array}{l}\text { Customers } \\
\text { (Competitors) } \\
\text { Senior } \\
\text { Management } \\
\text { Owners } \\
\text { Low costs }\end{array}$ & $\begin{array}{l}\text { Employee } \\
\text { awareness } \\
\text { Scale economy }\end{array}$ & $\begin{array}{l}\text { Competitors } \\
\text { Financial issues } \\
\text { LSP's } \\
\text { management } \\
\text { support }\end{array}$ & $\begin{array}{l}\text { Competitors if } \\
\text { green matters } \\
\text { Financial issues } \\
\text { LSP's ability to } \\
\text { share info }\end{array}$ & $\begin{array}{l}\text { Customers } \\
\text { (Environmental } \\
\text { legislation) } \\
\text { Low costs }\end{array}$ & $\begin{array}{l}\text { Senior } \\
\text { management }\end{array}$ \\
\hline \multicolumn{6}{|c|}{ SHIPPERS' INHIBITORS TO SUCCESS } \\
\hline $\begin{array}{l}\text { Customers do not } \\
\text { want to pay } \\
\text { Numerical debates } \\
\text { Low payback on } \\
\text { investments }\end{array}$ & $\begin{array}{l}\text { LSP's behaviour } \\
\text { Limited resources } \\
\text { Cost increase }\end{array}$ & $\begin{array}{l}\text { LSPs' poor } \\
\text { green } \\
\text { performance }\end{array}$ & $\begin{array}{l}\text { LSPs' poor } \\
\text { green } \\
\text { performance }\end{array}$ & $\begin{array}{l}\text { Low strategic } \\
\text { importance }\end{array}$ & $\begin{array}{l}\text { Varying customer } \\
\text { demands } \\
\text { Low senior } \\
\text { management } \\
\text { engagement }\end{array}$ \\
\hline
\end{tabular}

(CSFs of less importance but still with an influence are in brackets)

Table 8 indicates that there is considerable variation on the shipper side, although similar CSFs and inhibitors are present. The shippers' customers play a crucial role in how they approach their LSPs. If environmental considerations are important to these customers, the findings suggest that a green LSP may contribute to the shippers' competitive advantage. For example, IRL 1 noted that "satisfying the changing needs of our large retail multiple customers is of paramount importance to us". However, customers can also be inhibitors to green development, in particular when cost factors are deemed to be important - "An important obstacle to introducing environmental efforts is the situation where investments don't show a clear pay-back." (SWE 1) and "A critical inhibiting factor is the scarcity of financial resources and economic incentives" (ITA 1). In line with this, shippers generally see their customers' unwillingness to pay for green initiatives as a major inhibitor to the greening of logistics processes undertaken by LSPs. For example, 
SWE 1 stated that "Even if environmental improvements cost only a bit more the customer is not willing to pay for this.". This is in line with previous research (see, for example: Björklund, 2011; Sallnäs and Huge-Brodin, 2018).

Overall, the influence on shippers emanates mainly from their customers - for example, IRL1 stated specifically that "an LSP could never be a driver for us in greening our operations". However, as several of the shippers state, poor green LSP performance can be an inhibitor. For example, ITA 2 stated that "The support of logistics service providers is also very important for us. Nevertheless, it often happens that logistics companies are not able to provide us with satisfactory environmental performance. This is the most important inhibitor to developing more sustainable logistics".

Management attention is also mentioned as important both as a driver and when absent, as an inhibitor. For example, IRL 2 noted that "Senior management commitment is the key to driving environmental improvement. Without it, nothing happens". Legislation is barely mentioned, which is not surprising as very little legislation relevant to greening logistics is directed towards shippers (see, for example: Huge-Brodin et al, 2013).

RQ3 reads: What are the critical success factors and/or inhibitors to success with regard to environmental alignment between LSPs and shippers? Based on the foregoing, an appropriate response to RQ3 is: In relation to the environmental dimension, customers of the shippers can be both CSFs and inhibitors, with their requirements communicated to the LSPs by the shippers. An overall inhibitor to greening logistics appears to be unwillingness among shippers - often influenced by their customers - to incur additional cost or share investment. Overall, this illustrates that environmental requirements become aligned along the supply chain starting with end-customer demands. Further, top management in both shippers and LSPs play a vital role, while the role of legislation appears as negligible, hence the findings point to an alignment between LSPs and shippers regarding the influence of financial factors (high influence), top management (high influence) and legislation (low degree of influence).

The stakeholder theory guiding principles previously developed by the authors based on their refined stakeholder theory model (see Figure 3) were then followed in the search for a deeper understanding of the issues related to RQ3.

Our response to RQ3 is broadly in line with Freeman et al. (2010) and Kirchoff et al. (2011) stressing the influence of primary stakeholders over that of secondary stakeholders. Here it can also be seen - thanks to the dual perspective adopted by the authors - how this influence can be transferred through the supply chain, thus elevating the importance of the shippers' primary stakeholders to the LSPs. A possible explanation of the authors' response to RQ3 is therefore: for LSPs it is ultimately the end-users and their requirements that drive the LSPs' adoption of green initiatives.

As legislative authorities and suppliers play a relatively small role, they do not contribute to any overlapping influence as suggested by Post et al. (2002). Even in situations where customer pressure is relatively weak, strong management commitment can create the impetus for going green. However, if this is not coupled with a favourable financial situation then the room for improvement is limited by what customers are willing to pay for. 
It is not possible based on this sample, to group the responses of the various companies according to firm size, as done by Wong and Fryxell (2004). However one characteristic that seems to make a difference is the country of origin. Swedish firms - LSPs in particular - place a strong emphasis on employees as CSFs; Italian firms placed less emphasis on this factor, while it was not mentioned among the Irish firms. In turn, this might point to historical, political as well as cultural differences between countries. A further insight into $\mathrm{RQ2}$, therefore, might be: the role of employees as CSF differs according to cultural characteristics.

\section{Conclusions and implications}

In this final section, the overall findings of the research are presented in the form of a summary of the conclusions and insights that were generated. Managerial and policy implications are then presented, and the article concludes by highlighting the main limitations of the current study and by suggesting some potentially fruitful areas for further research.

\subsection{Summary of conclusions and insights}

The purpose of this article is to develop a better understanding of the nature of the alignment between LSPs and shippers regarding greening logistics. The article takes a conceptual approach to LSP/shipper alignment, in which the findings from the investigated cases form the basis for the analysis. The responses to the research questions shed light on different dimensions of this alignment. One conclusion from the research is that in relation to the environmental dimension of logistics, ambition levels, as well as the actual offerings and requirements, are poorly aligned. As the development of initiatives may be predicated on ambition levels, it is logical that the alignment differs in the same way: while LSPs demonstrate higher ambition levels as well as concrete and detailed offerings, shippers demonstrate lower ambition levels for greening logistics, and more general and standardised requirements for green logistics services. A potential for improved alignment between LSPs and shippers resides in the still relatively high general environmental ambition levels of shippers.

On the other hand, the CSFs and inhibitors to success provide similar patterns for LSPs and shippers. Customers are an important CSF, but can also be an inhibitor to success. Furthermore, both LSPs and shippers perceive financial factors and top management as important CSFs, while the influence of environmental legislation plays a negligible role for both LSPs and shippers. This common perception per se provides a basis for future joint development. In particular, shippers' customers have a strong influence on what is practically achievable in terms of green logistics, which in turn underlines the importance of taking a supply chain perspective. While the focal entity in this research was the alignment between the LSP and shipper sides, the stakeholder model has facilitated the inclusion of other stakeholders in the analysis, in this case the shippers' customers.

To improve understanding of the situation, three guiding principles derived from stakeholder theory were applied. These guiding principles supported the finding that the shippers' customers are important stakeholders, mainly as they are primary stakeholders to the shippers (and thereby primary stakeholders to the LSPs' primary stakeholders - i.e. 
the shippers). Moreover, LSPs tend to align to their most demanding customers, which elevates ambitious shippers to important primary stakeholders for the LSPs.

The guiding principles helped to lift the perspective from a purely LSP-shipper dyadic one in other ways, and in particular highlighted the importance of influence from weaker secondary stakeholder groups. Taken together, the influence from competitors, suppliers, legislation, employees - and perhaps the increased interest from wider society - has made LSPs more likely to develop greener practices and processes. This is despite the apparent reluctance of customers to incur additional cost or, in some cases, to even require more environmentally sustainable services from LSPs. Hence, the sum of the various influences from many secondary stakeholders may together exert greater pressure for change.

With respect to company characteristics that may modify the alignment between LSPs and shippers, the findings taken through the prism of the stakeholder theory guiding principles suggest that smaller LSPs appear to align more closely with shippers than larger LSPs. Larger LSPs often have more standardised operations and need to serve a multitude of shippers, whereas smaller LSPs appear to be more oriented to finding solutions and responding quickly to shippers' requirements - and consequently to become more aligned. Cultural characteristics may also moderate in particular the alignment between CSFs (e.g. the role of other employees than top management in Swedish companies alluded to in section 4.3).

\subsection{Research contributions}

The authors developed their three research questions (RQs) based on an extensive review of the relevant extant literature. Their responses to each RQ - i.e. as set out in section 4.1, 4.2 and 4.3 - both reinforce existing understanding of the phenomena under investigation and provide new insights. On the one hand, the findings from this research reinforce those of, for example, Bjorklund (2011) and Wong and Fryxell (2004) in relation to RQ1. Compared to Martinsen and Björklund (2012) and to Martinsen and Huge-Brodin (2014), the findings concerning RQ2 relate to a wider cultural context, including case companies from Sweden, Ireland and Italy. On the other hand, insights into the paradoxical position of customers discussed in section 4.3 contribute new insights building on the work of, for example, Sallnäs and Huge-Brodin (2018). Finally, while each of the RQs in this study has been addressed to some extent in prior research, the combination of the current interconnected research questions, inspired by Gattorna (1998), makes a novel contribution and adds new insights.

The methodology adopted in this article sought to develop new and fresh insights from the analysis of empirical data, as well as from reflection on that analysis through the prism of an appropriate theoretical framework. The use of stakeholder theory in this context was very fruitful. In the case of each RQ, guiding principles derived from this theory allowed the authors to develop a deeper understanding of the associated phenomena. This understanding is reflected in the possible explanations of the original responses to the RQs posited by the authors, based on the data analysis facilitated by the guiding principles, as well as in the refined responses and possible explanations developed in each case. Thus, the analytical prism applied to all three RQs also confirms their interconnectedness.

The way in which the authors applied the stakeholder theory builds on an extension of the original model by Freeman (1984), developed specifically for a supply chain context 
(see Figure 3). This novel use of stakeholder theory underlines its usefulness in supply chain research, and in particular highlights the importance of the influence exerted by stakeholders outside a focal dyad. In comparison to the original model (Figure 1), the new version presented in Figure 3 allows for a more equal analysis of two focal firms, instead of one. In comparison to the model presented in Figure 2 - describing primary and secondary stakeholders - the model in Figure 3 allows to highlight the specific importance of the shippers' customers to the LSPs. The shippers' customer are in essence indirect stakeholders to the LSPs, nevertheless their influence on them, mediated by the shippers, shapes and frames the activities and ambition levels of the LSPs to a high extent. Hence, the new version of the stakeholder model, as presented in Figure 3, supports the basic conceptions of supply chain management, and should thus be useful in other supply chainlike actor constellations. In particular, the new model acknowledges a focus on two actors instead of one, and includes the stakeholders of each actor group. The new model thereby emphasises the relatively high influence that a distant actor type (e.g. the final consumer) might have on one of the actors in a dyadic or market constellation. This is in line with the core SCM principle that the management of the (whole) supply chain should be driven by customer demand (see, for example: Sweeney et al, 2018).

\subsection{Managerial implications}

It was noted above that the work of John Gattorna (see, for example: Gattorna, 1998) provided some of the inspiration for the research described in this article. Reflecting on the insights developed from this research, it is interesting to note that each element of the Gattorna strategic alignment model provides some pointers in terms of implications for supply chain practitioners. First, it is clear from the findings that the demands of end users or consumers play a key role in determining both ambition levels and actual practices in firms along the supply chain. Second, this research suggests that the development of more environmentally sustainable logistics practices is predicated on what Gattorna refers to as the "strategic response" of firms to these market pressures. Third, this research suggests that the cultural capability and leadership styles present in firms impacts on the way in which green practices develop (see section 4.3).

Alignment in this context includes the need for more collaborative approaches to the development of greener logistics practices. Whilst the responses to RQ1 and RQ2 provide some insights in this regard, the discussion in relation RQ3 is more instructive from a practitioner perspective. The CSFs and inhibitors to success derived from the data analysis, and refined by reflection through the prism of the stakeholder theory guiding principles (see section 4.3), identify areas where a particular focus could be impactful. For example, key role of end users and consumers points to the need for LSPs and shippers to jointly develop shared understandings of environmental aspects of end user requirements.

Finally, much of this research points to a quite high level of understanding of green logistics and a recognition of the strategic importance of improving environmental performance (see section 4.1). However, as shown in our response to RQ2 (see section 4.2) the evidence also suggests that actual practices are poorly aligned. This perhaps points to what Sweeney et al. (2018) referred to as an "understanding into action conundrum" or "implementation deficit disorder", in other words there is a clear understanding of what needs to be done and why but less clarity in terms of how to go 
about it. The fresh insights from this research into the CSFs (and inhibitors to success) offer normative guidance in this regard.

\subsection{Policy implications}

The key finding here is that legislative and regulatory pressures often appear to lag practice and play a relatively inconsequential role as a result. This, combined with the clear need for more supply chain wide perspectives, points to the need for new approaches to policy-making. Traditional approaches often emphasise strategically important sectors and industries rather than adopting a supply chain perspective (i.e. one that cuts across several sectors and industries). Among the researched companies, LSPs are those most exposed to various policy measures (e.g. combustion engine standards, environmental zones in cities and $\mathrm{CO}_{2}$ emission reports for customers). As the findings point to the crucial role of the primary stakeholder as a CSF, a consequence is that policy measures could be developed that encourage shippers, as well as end-customers, to require more exacting environmental standards from LSPs.

\subsection{Limitations and future research}

The authors' initial responses to their RQs are based on a small sample of firms from just three countries. Notwithstanding the fact that these firms deal with a wide variety of products and customers, it is impossible to generalise the conclusions. Nonetheless, reflection on the analysis of these data through the prism of stakeholder theory allowed us to develop fresh and deep insights. Future research can build on these insights, collecting appropriate data in other product and geographical settings. This would allow specific issues that emerged from the current study to be explored in more detail (e.g. the role of culture, the impact of firm size, and the path from understanding to action). It should also be noted that the decision to use stakeholder theory emerged from the authors' reflection on their data; this means that the data were not specifically collected with this theory in mind and are, therefore, not perfectly framed in this context. Another possible limitation of the current study is that specific dyads were not studied, i.e. the data comes from a number of LSPs and shippers that do not have direct relationships. The "dual" approach could be fruitfully extended - in line with Harland (1996) -to wider supply chains and networks.

There can be little debate about the importance or urgency of this work in the context of the evolving global landscape, and particularly given the increasingly challenging expectations being placed on firms (including shippers and their LSPs) for improving their environmental performance. Reflecting on the findings presented in this article, the authors are strongly of the view that effective collaboration is the key to this: collaboration between firms up and down supply chains; collaboration between supply chain actors and technology vendors; and, perhaps most important from a research perspective, collaboration between supply chain scholars and practitioners. 


\section{References}

Aronsson, H., and Huge Brodin, M. (2006) "Environmental impact of changing logistics structures", The International Journal of Logistics Management, 17(3): 394-415.

Ashenbaum B., Maltz A.B., and Rabinovich E. (2005) "Studies of trends in third-party logistics usage: what we can conclude?", Transportation Journal, Vol. 44 , No. 3, pp. 3950 .

Bajec, P., Tuljak-Suban, D., and Krmac, E. (2015) "Do ISO standards favour logistics provider efficiency, competitiveness and sustainability? A Slovenian perspective", International Journal of Logistics Management, Vol. 26, pp. 275-295.

Björklund, M. (2011) "Influence from the business environment on environmental purchasing - drivers and hinders of purchasing green transportation services", Journal of Purchasing and Supply Management, Vol. 17, pp. 11-22.

Bloemhof, J.M., van der Vorst, J.G.A.J., Bastl, M., and Allaoui, H. (2015) "Sustainability assessment of food chain logistics", International Journal of Logistics Research and Applications, Vol. 18, pp. 101-117.

Carter, C., Kale, R. and Grimm, C., (2000) "Environmental purchasing and firm performance: an empirical investigation", Transportation Research Part E: Logistics and Transportation Review, Vol. 36, No. 3, pp. 219-228.

Croom, S., Romano, P. and Giannakis, M. (2000), "Supply chain management: an analytical framework for critical literature review", European Journal of Purchasing and Supply Management, Vol. 6 No. 1, pp. 67-83.

Colicchia, C., Marchet, G., Melacini, M., and Perotti, S. (2013) "Building environmental sustainability: Empirical evidence from Logistics Service Providers", Journal of Cleaner Production, Vol. 59, pp. 197-209.

Deutsche Post DHL (2010) Delivering tomorrow. Towards Sustainable Logistics (http://www.dpdhl.com/en/logistics_around_us/sustainable_logistics.html

Easterby-Smith, M.P.V., Thorpe, R., and Jackson, P. (2008) Management Research: Theory and Research. Sage, London.

Eglese, R. and Black, D. (2010) "Optimizing the routing of vehicles", in McKinnon et al. (eds.) (2010) Green Logistics: Improving the environmental sustainability of logistics, KoganPage, pp. 215-228.

Ellram, L.M. and Golicic, S.L. (2015) “Adopting Environmental Transportation Practices", Transportation Journal, Vol. 54, 55-88.

Eltayeb, T.K., and Zailani, S. (2009) "Going green through green supply chain initiatives towards environmental sustainability", Operations and Supply Chain Management, Vol. 2, No. 2, pp. 93-110. 
Eng-Larsson, F. (2014) On the Incentives to Shift to Low Carbon Freight Transport, Doctoral dissertation, Faculty of Engineering, Lund University.

Evangelista P., Colicchia C., and Creazza A., (2017) "Is environmental sustainability a strategic priority for logistics service providers?", Journal of Environmental Management, Vol. 198, 353-362.

Evangelista, P. (2014) "Environmental sustainability practices in the transport and logistics service industry: An exploratory case study investigation", Research in Transportation Business and Management, Vol. 12, pp. 63-72.

Evangelista, P., Huge-Brodin, M., Isaksson, K. and Sweeney, E. (2012) “Purchasing green transport and logistics services: implications for small business", Piccola Impresa Small Business, No. 2, pp. 43-62.

Fassin, Y. (2009) “The stakeholder model refined”, Journal of Business Ethics, Vol. 84. No. 1, pp. 113-135.

Ferguson, D. (2011) “CSR in Asian logistics: Operationalisation within DHL (Thailand)", Journal of Management Development, Vol. 30, pp. 985-999.

Foerstl, K., Reuter, C., Hartmann, E. and Blome, C. (2010) "Managing supplier sustainability risks in a dynamically changing environment - Sustainable supplier management in the chemical industry", Journal of Purchasing and Supply Management, Vol. 16, pp. 118-130.

Foster, S.T., Sampson, S.E. and Dunn, S.C., (2000) "The impact of customer contact on environmental initiatives for service firms", International Journal of Operations and Production Management, Vol. 20, No. 2, pp. 187-203.

Freeman, R.E. (1984) Strategic management: a stakeholder approach. Pitman, Marshfield.

Freeman, R.E., Harrison, J., Wicks, A., Parmar, B., \& de Colle, S. (2010). Stakeholder theory: The state of the art. Cambridge, UK: Cambridge University Press

Gammelgaard, B. and Prockl, G. (2012) - Gammelgaard, B. and Prockl, G. (2012) "Innovating for Green Supply Chain Management: The logistics service providers' perspective", In Carlsson et al, (eds.), Rethinking Transport in the Øresund Region: Policies, Strategies and Behaviors, Lund University.

Gammelgaard, B. (2003): Case studies in logistics research, in: Juga, J. (ed.): Proceedings of the 15th Annual Conference for Nordic Researchers in Logistics NOFOMA, Oulu, Finland, pp. 556-567.

Gattorna, J. (1998) Strategic supply chain alignment: best practice in supply chain management, Aldershot, Hampshire, England.

Harris, I., Sanchez Rodrigues, V., Naim, M. and Mumford, C. (2010) "Restructuring of logistics systems and supply chains", in McKinnon et al. (eds) (2010) Green Logistics: Improving the environmental sustainability of logistics, Kogan Page: 101-123. 
Ho, Y., and Lin, C. (2012) “An Empirical Study on Taiwanese Logistics Companies' Attitudes toward Environmental Management Practices", Advanced Management Applied Economics, Vol. 2, pp. 223-241.

Huge-Brodin, M., Huemer, L., Jensen, J.K. and Arlbjørn, J.S. (2013) Sustainable Transports through Improved Actor Interfaces - End of Project Report. Norden Energy and Transport.

Isaksson, K. and Björklund, M (2010) “Developing sustainable logistics services”, in the Proceedings from the 22nd annual NOFOMA conference, Kolding, pp. 985-1000.

Isaksson, K. and Huge-Brodin, M. (2013) "Understanding efficiencies behind logistics service providers' green offerings”, Management Research Review, Vol. 36, nr 3, p. 216238

Isaksson, K. (2014) Logistics service providers going green - a framework for developing green service offerings. Doctoral Thesis, Dissertations No. 1600, Linköping studies in science and technology, Linköping University

Johannes, E., Ekman, P., Huge-Brodin, M. and Karlsson, M. (2018) "Sustainable timber transport: economic aspects of aerodynamic configuration", Sustainability, Vol. 10, nr 6, sp. 1-18

Jørsfeldt, L.M., Hvolby, H.-H., and Nguyen, V.T. (2016) "Implementing environmental sustainability in logistics operations: A case study", Strategic Outsourcing International Journal, Vol. 9, pp. 98-125.

Juga, J. (2003), “Case study in logistics organization analysis”, in Ojala L., Hilmola O.P. (ed. by), Case study research in logistics, Series B-1, Turku: Turku School of Economics and Business Administration, pp. 73-82.

Jumadi, H. and Zailani, S. (2010) "Integrating Green Innovations in Logistics Services Towards Service Sustainability: A Conceptual Paper”, Environmental Research Journal, Vol. 4, No. 4, pp. 261-271.

Kellner, F. and Igl, J. (2015) “Greenhouse gas reduction in transport: Analyzing the carbon dioxide performance of different freight forwarder networks", Journal of Cleaner Production, Vol. 99, pp. 177-191.

Kirchoff J. F., Koch, C. and Nichols, B.S. (2011) "Stakeholder perceptions of green marketing: the effect of demand and supply integration", International Journal of Physical Distribution \& Logistics Management, 41(7):684-696

Kohn, C. and Huge-Brodin, M. (2008) "Centralised distribution systems and the environment: how increased transport work can decrease the environmental impact of logistics", International Journal of Logistics: Research and Applications, 11(3): 229245.

Kudla, N.L. and Klaas-Wissing, T. (2012) "Sustainability in shipper-logistics service provider relationships: A tentative taxonomy based on agency theory and stimulusresponse analysis", Journal of Purchasing and Supply Management, Vol. 18, pp. 218-231. 
Lammgård, C., and Andersson, D. (2014) "Environmental considerations and trade-offs in purchasing of transportation services", Research in Transportation Business and Management, Vol. 10, pp. 45-52.

Langley, J.C. (2017), 21st Annual Third-Party Logistics Study: The State of Logistics Outsourcing, available at: http://www.3plstudy.com

Large, R. and Gimenez Thomsen, C., 2011. Drivers of green supply management performance: Evidence from Germany, Journal of Purchasing and Supply Management, 17: $176-184$.

Lieb, K. and Lieb, R., 2010. Environmental sustainability in the third-party logistics (3PL) industry, International Journal of Physical Distribution and Logistics Management, Vol. 40, No. 7, pp. 524-533.

Lin, C.Y. and Ho, Y.H. (2011), "Determinants of Green Practice Adoption for Logistics Companies in China”, Journal of Business Ethics, Vol. 98, pp. 67-83.

Marchant, C. (2010) "Reducing the environmental impact of warehousing", In: McKinnon A, Cullinane S, Browne M, Whiteing A (eds, 2010) Green logistics - improving the environmental sustainability of logistics. Kogan Page Limited, London

Martinsen, U. and Björklund, M. (2012) “Matches and gaps in the green logistics market”, International Journal of Physical Distribution and Logistics Management, 42(6):562583

Martinsen, U. and Huge-Brodin, M. (2014) "Environmental practices as offerings and requirements on the logistics market", Logistics Research, 7:115, pp. 1-22

Martinsen, U. (2014) Towards greener supply chains: Inclusion of environmental activities in relationships between logistics service providers and shippers, Doctoral Thesis, Dissertations No. 1565, Linköping Studies in Science and Technology, Linköping University.

McKinnon, A. C. (2018). Decarbonising Logistics - Distributing Goods in a Low Carbon World, Kogan Page (UK).

McKinnon, A. C. (2014) "The possible influence of the shipper on carbon emissions from deep-sea container supply chains: An empirical analysis", Maritime Economics and Logistics, Vol. 16, pp. 1-19.

McKinnon, A. C. (2015) "Environmental sustainability: A new priority for logistics managers", in McKinnon, A. C. Browne, M., Piecyk, M. and Whiteing, A. (eds, 3rd ed.) Green Logistics: Improving the environmental sustainability of logistics, Kogan Page, London, p. 3-31.

McKinnon, A. C. (2010) "Increasing fuel efficiency in the road freight sector", in McKinnon et al. (eds) (2010) Green Logistics: Improving the environmental sustainability of logistics, Kogan Page, London, p. 229-241

McKinnon, A. C. (2003) "Logistics and the Environment”, in David A. Hensher, Kenneth J. Button (ed.) Handbook of Transport and the Environment (Handbooks in Transport, Volume 4) , pp.665 - 685 
Murphy, P.R. and Poist, R.F. (2003) "Green perspectives and practices: a "comparative logistics" study", Supply Chain Management: An International Journal, Vol. 8, Iss: 2, pp. 122-131.

Nilsson, F.R., Sternberg, H., Klaas-Wissing, T. (2017). Who controls transport emissions and who cares? Investigating the monitoring of environmental sustainability from a logistics service provider's perspective. International Journal of Logistics Management, 28, 798-820.

Oberhofer, P. and Dieplinger, M. (2014) "Sustainability in the transport and logistics sector: Lacking environmental measures", Business Strategy and the Environment, Vol. 23, 236-253.

Pålsson, H., Kovàcs, G. (2014) "Reducing transportation emissions: A reaction to stakeholder pressure or a strategy to increase competitive advantage", International Journal of Physical Distribution and Logistics Management, Vol. 44, 283-304.

Perotti, S., Micheli, G.J.L., and Cagno, E. (2015) "Motivations and barriers to the adoption of green supply Chain practices among 3PLs", International Journal of Logistics Systems and Management, Vol. 20, 179-198.

Perotti, S., Zorzini, M., Cagno, E. and Micheli, G.J.L. (2012) “Green supply chain practices and company performance: The case of 3PLs in Italy", International Journal of Physical Distribution and Logistics Management, Vol. 42, pp. 640-672.

Piecyk, M., 2010. Carbon auditing of companies, supply chains and products, in McKinnon et al. (eds) (2010) Green Logistics: Improving the environmental sustainability of logistics, Kogan Page: 49-67.

Post, J.E., Preston, L.E. and Sachs, S. (2002) "Managing the extended enterprise: the new stakeholder view", California Management Review 45(1):6-28

Rao, P. and Holt, D. (2005). "Do green supply chains lead to competitiveness and economic performance?", International Journal of Operations \& Production Management, 25(9): 898-916.

Rossi, S., Colicchia, C., Cozzolino, A. and Christopher, M. (2013) "The logistics service providers in eco-efficiency innovation: An empirical study", Supply Chain Management: An International Journal, Vol. 18, pp. 583-603.

Salhieh, L., and Abushaikha, I. (2016) "Assessing the driving forces for greening business practices: Empirical evidence from the United Arab Emirates' logistics service industry", South African Journal of Business and Management, Vol. 47, pp. 59-69.

Sallnäs, U. and Huge-Brodin, B. (2018) "De-greening of logistics? - Why environmental practices flourish and fade in provider-shipper relationships and networks", forthcoming in IMM, available online 10.1016/j.indmarman.2018.07.001

Sallnäs, U. (2016) "Coordination to manage dependencies between logistics service providers and shippers an environmental perspective", International Journal of Physical Distribution and Logistics Management, Vol. 46, pp. 316-340. 
Sarkis, J., Zhu, Q. and Lai, K.H. (2011), “An organizational theoretic review of green supply chain management literature", International Journal of Production Economics, Vol. 130 No. 1, pp. 1-15.

Srivastava, S.K. (2007), "Green supply-chain management: A state-of-the-art literature review”, International Journal of Management Reviews, Vol. 9 No. 1, pp. 53-80.

Storey, J., Emberson, C., Godsell, J., Harrison, A. (2006) “Supply chain management: theory, practice and future challenges", International Journal of Operations \& Production Management, Vol. 26, No.7, pp.754-774.

Sweeney, E., Grant, D.B. and Mangan, J.D. (2018) "Strategic adoption of logistics and supply chain management", International Journal of Operations \& Production Management, Vol. 38 Issue 3, pp.852-873.

Tacken, J., Sanchez Rodrigues, V. and Mason, R. (2014) “Examining CO2e reduction within the German logistics sector", International Journal of Logistics Management, 25, 54-84.

Tundys, B. and Wisniewski, T. (2018) "The Selected Method and Tools for Performance Measurement in the Green Supply Chain - Survey Analysis in Poland", Sustainability, 10, 549.

Vachon, S. (2007) "Green supply chain strategies and the selection of environmental technologies", International Journal of Production Research, Vol. 45, Nos. 18-19, 43574379.

Vachon, S. and Klassen, R., 2006. Extending green practices across the supply chain: the impact of upstream and downstream integration, International Journal of Operations \& Production Management, 26(7): 795-821.

van Hoek, R.I. and Johnson, M., 2010. Sustainability and energy efficiency. Research implication from an academic roundtable and two case examples, International Journal of Physical Distribution and Logistics Management, 40 (1/2): 148-158.

Vieira, J.G.V., Mendes, J.V., Suyama, S.S., 2016. Shippers and freight operators perceptions of sustainable initiatives. Evaluation and Program Planning, 54: 173-181.

Walker, H., Di Sisto, L. and McBain, D., 2008. Drivers and barriers to environmental supply chain management pratices: Lessons from the public and private sectors, Journal of Purchasing and Supply Management, 14: 69-85.

Weijers, S, Glöckner H.-H. and Pieters, R. (2012) Logistic service providers and sustainable physical distribution. Logistikdienstleister und Nachhaltige Distribution 8(2):157-165

Wolf, C. and Seuring, S., 2010. Environmental impacts as buying criteria for third party logistical services, International Journal of Physical Distribution \& Logistics Management, 40(1): 84-102. 
Wong, L.T. and Fryxell, G. E. (2004) "Stakeholder Influences on Environmental Practices: A Study of Fleet Operations in Hong Kong", Transportation Journal, Vol. 43, pp. 22-35.

Woodburn, A. and Whiteing, A., 2010. Transferring freight to 'greener' transport modes, in McKinnon et al. (eds) (2010) Green Logistics: Improving the environmental sustainability of logistics, Kogan Page: 124-139.

Yen, Y-X and Yen, S-Y (2012) Top-management's role in adopting green purchasing standards in high-tech industrial firms", Journal of Business Research, Vol 65, Iss. 7, pp. 951-959.

Zhu, Q. and Sarkis, J. (2004), "Relationships between operational practices and performance among early adopters of green supply chain management practices in Chinese manufacturing enterprises, Journal of Operations Management, Vol. 22 No. 3, pp. 265-289

Zsidisin, G. and Siferd, S., 2001. Environmental purchasing: a framework for theory development, European Journal of Purchasing and Supply Management, 7(1): 61-73. 